\section{8. 結}

以上が鉄鋼技術共同研究会特殊鋼部会の昭和 30 年 11 月 から昭和34年 2 月まで10回の審議の概要であある. 一応 の結論を得ているものもあるが，未完で中止し，あるい は予備調査の段階にとどまつているものもある.

昭和34年 6 月から新に関東製鋼(梀), 日本金属工業(株), 日本高周波工業(㧣), 日本冶金工業(侏)の 4 社の加入を得, 合計20社となり委員も一新して益々盛会裡に討議を続行 している. 本取縓めの結果選ばれた（1)鋼塊肌の改善に 関する研究, (2)造塊用耐火物に関する研究, (3)砂疪防止 に関する研究，(4)押湯保温に関する研究，の4 議題に対 しては, その後昭和35年 6 月までに 5 回の研究会が催さ れた。この間提出された報告は145 部におよび,一応資 料も出揃い再び取絙めの時期に達し, 昭和35年10月から は溶解を主体とした新しい議題に移ることになつた。こ れら新しい資料は 6 章, 7 章に述べた予備調査に続く本 調査であり興味をひく研究が多い，すなわち双方を合せ て始めて完全となるものであり，この取縓めが後日再び 本会誌に発表できる時期の速かなることを願 らのであ る.ここにその概要を記して本報告の補いとしたい.

1) 鋼塊肌改善に関寸る研究

各種鋳型塗料の調査が進み, 従来のタール系, 樹脂系 に加えて弗化物系, 塩化物系が試用され，単なるスプラ ッシュ防止を離机無酸化雾囲気の造成, さらには強制脱 水素力も備えた鋼塊肌の本質的改善を狙 また純粋な無酸化雾囲気鋳造を求めて窒素, アルゴン等 の不活性ガスの中で䤻造し，あるいは油を滴下させつつ 注型する考案もあり，いずれる効果は大きく実用に近づ いている.スプラッシュ防止の目的には鋳型内面に Al 板, 耐火纸, 硝子布を插入または張着ける試験もある. 本質的な改善として上注法を下注法に転換することも多 く, 下注の肌改善の効果をさらに高めるため, 浮板, 発 煙紙も利用される. また基本的に鋳型内面と鋼塊肌の関 連を求め鋳型の管理設計の改良を試みたものもある.

2)造塊用耐火物に関する研究

取鍋煉瓦の改善が最も多く取上げられた，取鍋の能率 的な回転使用と原単位の低减, および鋼材品質上非金属 介在物の減少を目標とし, 耐蝕性に信れた寿命の長い煉
瓦の採用が主眼となつている. 炭珪質, 高フルミナ質, スピネル質等いわゆる高級煉瓦が対象となるが，中です 炭珪質は種々の難点を解決し実用の域に達した。しいし 煉瓦の性能は現状以上を望まず低廉煉瓦を開拓する試み もある. 不焼成煉瓦の研究はその一例である. ノズ, ストッパー煉瓦の調査も盛んで, おのおのその性能を最 も発揮できる材質を選び，組合せで効果を増長させよう とする研究が多い.

3）砂疪防止に関する研究

砂疪の本質が基本的に追求される一方, 現実的な防止 方法も発表された. 砂疪は造塊用耐火物の溶損物の混入 と鋳造中の酸化が主因と推定される. 前者に対しては各 種煉瓦が検討され，後者に対しては無酸化管囲気の利用 が試みられた。無酸化䇰囲気には窒素またはフルゴンガ スを用い 4 社で試験したが，いずれも効果を認めている. また注型温度を上升させると砂疪は減少し，ある王延比 で地疪発生が最高となり，検査面の仕上げ方法で成綪が 異なり，鋼塊内部の砂疪分布に差異がある等の報告もあ り砂疪防止の対策が導かれている.

4）押湯保温に関する研究

発熱性保温煉瓦と電弧加熱の特色欠陷経済性等が詳絊 に検討された。押湯効果が顕著であるから，これらに転 換する気運となつている. 特に効果が安定していること および従前の保温剤の如き偏析の恐れの少ないことが好 まれる，価格的にやや難点のあつた発熱性保温煉瓦す製 造業者の努力と使用技術の向上から経費は半減し採用が 相続いている, 種類は Feedex とAlbroが殆んで,お のおのその特色を活かして用いられる.

以上特殊鋼部会報告書を取緾めるにあたり技術の進歩 に整くものがある. 当時最高の関心をあつめ論議の中心 であつた事柄も既に当然の常識となり，また調查が現在 であれば，より優れた内容と成果を举げ得ると考えられ るものも多い、特に理論より現実の作業系態を中心とし た調査であるから殊更この感が深くなる．部会の経緯を 示す意味で不満足のまま取緾めたが，今後機会を得てよ り完成にすることができれば幸いである。 